\title{
Water uptake by fresh Indonesian peat burning particles is limited by water-soluble organic matter
}

\author{
Jing Chen ${ }^{1}$, Sri Hapsari Budisulistiorini ${ }^{1}$, Masayuki Itoh ${ }^{2}$, Wen-Chien Lee ${ }^{1,3}$, Takuma Miyakawa ${ }^{4}$, \\ Yuichi Komazaki ${ }^{4}$, Liu Dong Qing Yang ${ }^{1,5}$, and Mikinori Kuwata ${ }^{1,2,5}$ \\ ${ }^{1}$ Earth Observatory of Singapore, Nanyang Technological University, Singapore, Singapore \\ ${ }^{2}$ Center for Southeast Asian Studies, Kyoto University, Kyoto, Japan \\ ${ }^{3}$ Division of Chemistry and Biological Chemistry, Nanyang Technological University, Singapore, Singapore \\ ${ }^{4}$ Research and Development Center for Global Change, Japan Agency for Marine-Earth Science and Technology, \\ Yokosuka, Japan \\ ${ }^{5}$ Asian School of Environment, Nanyang Technological University, Singapore, Singapore \\ Correspondence to: Jing Chen (chen.jing@ntu.edu.sg) and Mikinori Kuwata (kuwata@ntu.edu.sg)
}

Received: 13 February 2017 - Discussion started: 27 March 2017

Revised: 3 August 2017 - Accepted: 29 August 2017 - Published: 28 September 2017

\begin{abstract}
The relationship between hygroscopic properties and chemical characteristics of Indonesian biomass burning (BB) particles, which are dominantly generated from peatland fires, was investigated using a humidified tandem differential mobility analyzer. In addition to peat, acacia (a popular species at plantation) and fern (a pioneering species after disturbance by fire) were used for experiments. Fresh Indonesian peat burning particles are almost non-hygroscopic (mean hygroscopicity parameter, $\kappa<0.06$ ) due to predominant contribution of water-insoluble organics. The range of $\kappa$ spans from 0.02 to 0.04 (dry diameter $=100 \mathrm{~nm}$, hereinafter) for Riau peat burning particles, while that for Central Kalimantan ranges from 0.05 to 0.06 . Fern combustion particles are more hygroscopic $(\kappa=0.08)$, whereas the acacia burning particles have a mediate $\kappa$ value (0.04). These results suggest that $\kappa$ is significantly dependent on biomass types. This variance in $\kappa$ is partially determined by fractions of water-soluble organic carbon (WSOC), as demonstrated by a correlation analysis $(R=0.65) . \kappa$ of water-soluble organic matter is also quantified, incorporating the 1-octanolwater partitioning method. $\kappa$ values for the water extracts are high, especially for peat burning particles $\left(A_{0}\right.$ (a whole part of the water-soluble fraction): $\kappa=0.18, A_{1}$ (highly watersoluble fraction): $\kappa=0.30$ ). This result stresses the importance of both the WSOC fraction and $\kappa$ of the water-soluble fraction in determining the hygroscopicity of organic aerosol particles. Values of $\kappa$ correlate positively $(R=0.89)$ with
\end{abstract}

the fraction of $m / z 44$ ion signal quantified using a mass spectrometric technique, demonstrating the importance of highly oxygenated organic compounds to the water uptake by Indonesian BB particles. These results provide an experimentally validated reference for hygroscopicity of organicsdominated particles, thus contributing to more accurate estimation of environmental and climatic impacts driven by Indonesian BB particles on both regional and global scales.

\section{Introduction}

In Southeast Asia, tropical peatland fires, which occur by combustion of both peat and vegetation, have become frequent during the last few decades (van der Werf et al., 2010; Reddington et al., 2014; Marlier et al., 2015; Spracklen et al., 2015; Stockwell et al., 2016). As one of the most important biomass burning types, the peatland fires keep smoldering for months, releasing huge amounts of greenhouse gases and fine particles to the atmosphere, impacting atmospheric radiation (Levine et al., 1999; Page et al., 2002; van der Werf et al., 2010). In addition, the peatland burning particles cause transboundary air pollution, influencing visibility and human health (Kunii et al., 2002; Wang et al., 2004; Marlier et al., 2013; Crippa et al., 2016; Koplitz et al., 2016). These regional and global climate impacts have been commonly evaluated using different models (e.g., large-eddy simula- 
tion and global climate models) but with large uncertainties likely due to the inaccurate estimation of cloud condensation nuclei $(\mathrm{CCN})$ number concentration and subsequent cloud formation and precipitation processes (Mircea et al., 2005; Rose et al., 2010; Bougiatioti et al., 2016). One of the essential uncertainty contributors to the complex aerosol-cloudprecipitation interactions is water uptake properties of peatland burning particles, as water vapor alters aerosol physical and chemical characteristics, such as particle diameter.

Water uptake properties of biomass burning particles, including those emitted from peatlands, have been explored in a laboratory through measurements of hygroscopic growth and CCN activity (Chand et al., 2005; Dusek et al., 2005, 2011; Day et al., 2006; Petters et al., 2009; Carrico et al., 2010). In general, freshly emitted biomass burning particles have been found to be hygroscopic. For instance, the reported range of hygroscopicity parameter, $\kappa$, which serves as a metric for water uptake properties, varies from weakly $(\kappa=$ $0.02)$ to highly hygroscopic $(\kappa=0.80)$ (Day et al., 2006; Petters and Kreidenweis, 2008; Petters et al., 2009; Carrico et al., 2010). A field observation of water uptake properties of Indonesian biomass burning plumes also demonstrated that these particles are hygroscopic, with a median hygroscopic growth in light scattering $(f(\mathrm{RH}))$ of 1.65 between 20 and $80 \%$ relative humidity $(\mathrm{RH})$ (Gras et al., 1999). On the other hand, freshly emitted Indonesian peat burning particles generated in a laboratory were suggested to be non-hygroscopic with respect to quite a low $f(\mathrm{RH})=1.05$ at $90 \% \mathrm{RH}$ (Chand et al., 2005), and they were almost CCN inactive especially for particles larger than $150 \mathrm{~nm}$ (equivalent to $\kappa=0.05$ for $100 \mathrm{~nm}$ particles, calculated with an assumed surface tension of $0.072 \mathrm{Nm}^{-1}$ at $25^{\circ} \mathrm{C}$ ) (Dusek et al., 2005). The uniqueness of water uptake properties of freshly emitted Indonesian peatland burning particles as well as the discrepancy between the previously reported laboratory and field data needs to be consistently understood based on their chemical compositions for accurate evaluation on the environmental impacts.

Chemical composition of biomass burning particles, including those from Indonesian peatland fires, is dominated by a complex mixture of organic species (Jimenez et al., 2009; $\mathrm{Ng}$ et al., 2010; Cubison et al., 2011; Stockwell et al., 2016). The complexity in chemical composition inhibits understanding their water uptake properties at molecular levels (Asa-Awuku et al., 2008; Psichoudaki and Pandis, 2013; Riipinen et al., 2015). To overcome this difficulty, classification of organic compounds using multiple solvents (Carrico et al., 2008; Polidori et al., 2008; Chen et al., 2016), liquid-liquid extraction using 1-octanol and water (Kuwata and Lee, 2017), and solid-phase extraction (Asa-Awuku et al., 2008) has been conducted. Functional-group analysis of segregated organic matter has also been demonstrated as a strong tool to characterize complex mixture of organic compounds (Chen et al., 2016). For instance, chemical characteristics of water-soluble organic matter (WSOM) have been intensively investigated, revealing that WSOM predominantly consists of levoglucosan-like species, carboxylic acids, aldehydes, ketones, aliphatic alcohols, and polyacids (Decesari et al., 2000; Peng et al., 2001; Suzuki et al., 2001; MayolBracero et al., 2002; Chan et al., 2005; Psichoudaki and Pandis, 2013). Recently, the important roles of functional groups in water uptake properties were also investigated by both theoretical and experimental approaches (Suda et al., 2014; Petters et al., 2016).

In this study, hygroscopic growth of Indonesian peatland burning particles was investigated in a series of laboratory experiments to understand the relationships between water uptake properties and chemical characteristics. Hygroscopic growth of various types of fresh peat burning particles, along with those originating from combustion of dried peatland plants, was measured using a humidified tandem differential mobility analyzer (HTDMA) for the first time. Chemical characterization was also conducted using the Aerodyne Time-of-Flight Aerosol Chemical Speciation Monitor (ToFACSM). In addition, ratios of water-soluble organic carbon (WSOC) to organic carbon (OC) were quantified. The concurrent HTDMA and ToF-ACSM measurements were also performed for the bulk WSOM and its highly hydrophilic fraction classified with the 1-octanol-water partitioning method in terms of water solubility (Kuwata and Lee, 2017). This method provides a new angle (i.e., water solubility) to characterize chemical properties of WSOM, facilitating a more detailed investigation of particle water uptake properties with the first application of the method in HTDMA measurements of a highly hydrophilic organic fraction. These data were synergistically combined to provide a detailed picture of water uptake properties of freshly emitted Indonesian peatland burning particles.

\section{Experiment}

\subsection{Combustion setup}

Figure 1a shows the experimental setup. Peat and biomass samples were collected at peatlands in Riau and Central Kalimantan provinces in Indonesia (Table 1). The sampling sites include both burnt and undisturbed forest areas. In this region, peatland fire frequently recurs, and vast areas experience regeneration of vegetation after fire events. The peat samples were segregated for different sampling depths, as detailed in Table 1. Two other types of biomasses from Riau, including Pteridium aquilinum (called fern here) and leaves of Acacia mangium (abbreviated as acacia), were also employed for the experiment. Fern is one of the major pioneer species after peatland fires (Aswin et al., 2004). Acacia is one of the representative trees for plantations over drained peatland. Both acacia and fern samples were dried at ambient temperature after sampling. Further detailed information on the biomass samples is available in Budisulistiorini et al. (2017). 


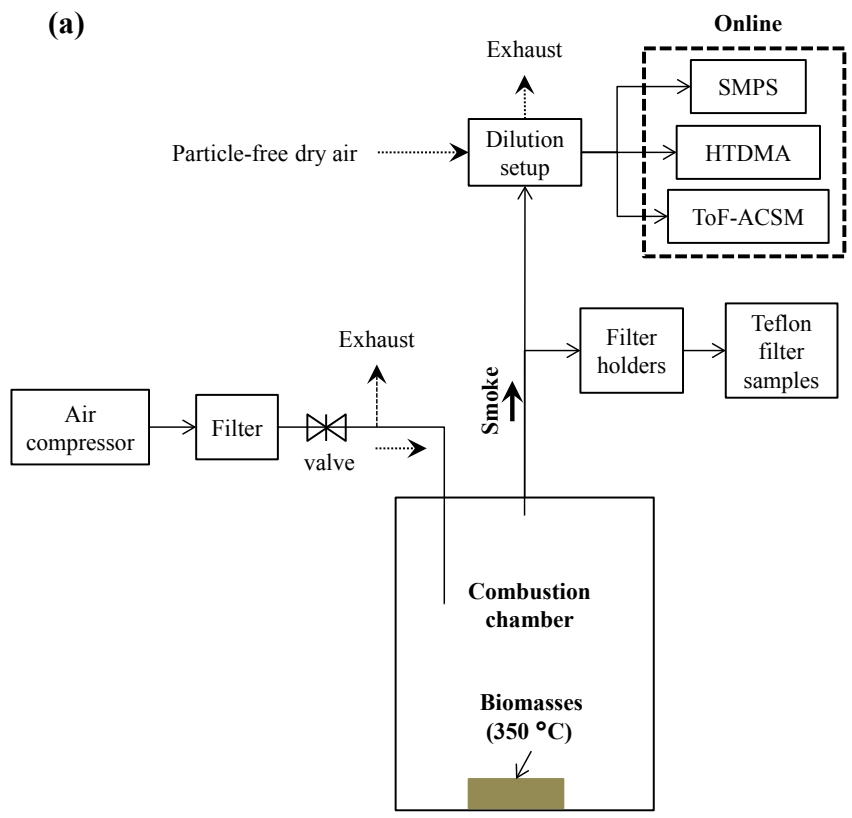

(b)

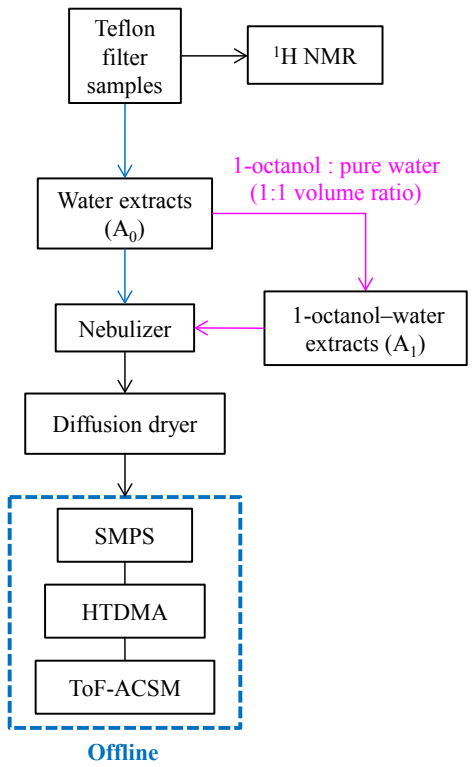

Figure 1. Schematic diagrams of the laboratory experimental setups. (a) The experimental setup for combustion experiment and subsequent online measurements, and (b) experimental setup for offline measurements of water extracts ( $A_{0}$, blue arrows) and 1-octanol-water extracts ( $A_{1}$, magenta arrows) from the filter samples.

Table 1. Summary of Indonesian peat and biomasses used for the laboratory combustion experiments. Samples 9, 15, and 16 were also used for offline experiments of their aqueous extracts $\left(A_{0}\right.$ and $\left.A_{1}\right)$.

\begin{tabular}{|c|c|c|c|c|c|}
\hline Exp. no. & Sample name & Sample depth $(\mathrm{cm})$ & Type/species & Location & Description \\
\hline 1 & Riau-1 & Surface $\sim 10$ & Peat & Riau, Sumatra & $D \& B^{a}$ peatland \\
\hline 2 & Riau-1.1 & $10-20$ & Peat & Riau, Sumatra & $D \& B^{a}$ peatland \\
\hline 4 & Riau-2 & Surface $\sim 10$ & Peat & Riau, Sumatra & $D \& B^{a}$ peatland \\
\hline 5 & Riau-2.1 & $10-20$ & Peat & Riau, Sumatra & $D \& B^{a}$ peatland \\
\hline 6 & Riau-2.2 & $30-40$ & Peat & Riau, Sumatra & $\mathrm{D} \& \mathrm{~B}^{\mathrm{a}}$ peatland \\
\hline 9 & Riau- $4^{\mathrm{c}}$ & Surface $\sim 10$ & Peat & Riau, Sumatra & $\mathrm{D} \& \mathrm{~B}^{\mathrm{a}}$ peatland \\
\hline 10 & Riau-4.1 & $10-20$ & Peat & Riau, Sumatra & $\mathrm{D} \& \mathrm{~B}^{\mathrm{a}}$ peatland \\
\hline 11 & Riau-SF & Surface $\sim 5$ & Peat & Riau, Sumatra & Secondary forest \\
\hline 12 & Riau-Zam & Surface $\sim 5$ & Peat & Riau, Sumatra & Undisturbed peat forest \\
\hline 13 & C.K.-DF & Surface $\sim 5$ & Peat & Palangkaraya, Central Kalimantan & $\mathrm{D} \& \mathrm{UB}^{\mathrm{b}}$ peat forest \\
\hline
\end{tabular}

${ }^{a}$ D\&B stands for the drained and burnt condition.

b D\&UB represents the drained but unburnt case.

c Teflon filter samples were collected during online combustion experiments.

$\mathrm{n} / \mathrm{a}$ : not applicable.

The biomass samples were used without desiccation. Approximately $1.0 \mathrm{~g}$ of biomass sample was combusted in a sealed $100 \mathrm{~L}$ stainless-steel container using a crucible, which was heated at $350^{\circ} \mathrm{C}$ by a ribbon heater, thermocouple, and proportional-integral-derivative (PID) controller (Kuwata et al., 2017). The target heating temperature was normally achieved within 2-3 min. Visual inspection confirmed that the combustion condition was mostly smoldering, consistent with a previous report (Usup et al., 2004). Particle-free air was continuously supplied to the container. Excess amount 
of particle-free air was released to the laboratory, allowing the experiments to be conducted at room pressure. Particles generated by the burning experiments were diluted by a twostage dilution system. Size distributions of biomass burning particles were measured using the Scanning Mobility Particle Sizer (SMPS, TSI Inc.). The measurement range of the SMPS was set as $14.6-685.4 \mathrm{~nm}$, and time resolution was 3 min. Chemical compositions of particles were quantified using the Aerodyne ToF-ACSM (Fröhlich et al., 2013), while water uptake properties were measured using the HTDMA (Massling et al., 2003, 2007; Duplissy et al., 2009). Online instruments such as SMPS, ToF-ACSM, and HTDMA were all operated following the dilution. Each combustion experiment lasted for $\sim 1 \mathrm{~h}$. Detailed descriptions of the ToFACSM and HTDMA are provided in the following sections.

Two filter samples were also collected simultaneously for each of the experiments. Particles were collected onto two $47 \mathrm{~mm}$ diameter filters housed in stainless-steel filter holders (BGI Inc.) for half an hour at flow rates of $5.0 \mathrm{~L} \mathrm{~min}^{-1}$. Teflon filters $\left(0.2 \mu \mathrm{m}\right.$ pore size, Fluoropore ${ }^{\mathrm{TM}}$, Sigma Aldrich) were used for WSOM samples, while quartz filter samples were employed for carbon analysis by the thermal-optical method. The collected samples were stored under refrigeration at $-20^{\circ} \mathrm{C}$ until analysis.

\subsection{Extraction and nebulization of WSOM}

Filter samples were extracted using approximately $20 \mathrm{~mL}$ of ultrapure water (Type I) by sonicating them for $30 \mathrm{~min}$ at room temperature. The resulting solutions were filtered through $0.2 \mu \mathrm{m}$ PTFE syringe filters (514-0070, VWR), yielding water extracts (denoted as $A_{0}$, i.e., a whole part of or the bulk water-soluble fraction). An aliquot of $A_{0}$ was mixed with the same volume $(5 \mathrm{~mL})$ of 1-octanol (Wako first grade, Wako) using a separatory funnel for classification by 1-octanol-water extraction (Valvani et al., 1981). The aqueous phase following the 1-octanol-water extraction is denoted as $A_{1}$ (slightly less than $5 \mathrm{~mL}$ ), corresponding to the highly water-soluble fraction. Details of the extraction method are provided in Kuwata and Lee (2017).

The aqueous solutions were nebulized using a glass nebulizer. A mass flow controller (MC-20 SLPM-D, Alicat Scientific, Inc.) was used to regulate the flow rate $\left(3.5 \mathrm{~L} \mathrm{~min}^{-1}\right)$ of particle-free air supplied to the nebulizer. Following nebulization, the sample was desiccated by a diffusion dryer (model 42000, Brechtel Manufacturing, Inc.) filled with silica gel (Chameleon 83000.360, VWR International). The desiccated particles were measured using the HTDMA, ToFACSM, and SMPS. The analysis of $A_{0}$ and $A_{1}$ was conducted only for peat (sampled from a burnt area, Riau-4), acacia, and fern samples.

\subsection{HTDMA}

Hygroscopic growth of particles was measured using the HTDMA (Massling et al., 2003, 2007; Duplissy et al., 2009; Gysel et al., 2009). The HTDMA system consists of three major components: (1) the first DMA (TSI Inc. model 3081) to select monodisperse particles of a specific diameter, (2) the humidification unit for hydrating the classified particles at a target RH, and (3) the second DMA (TSI Inc. model 3081) and a condensation particle counter (CPC, TSI Inc. model 3775) to detect humidified size distributions (Fig. S1 in the Supplement).

Aerosol particles were dried using a diffusion dryer (model 42000, Brechtel Manufacturing, Inc.), and introduced to the first DMA at a flow rate of $0.3 \mathrm{~L} \mathrm{~min}^{-1}$. The first DMA selected 50, 100, and $200 \mathrm{~nm}$ particles. Both the first and second DMAs were operated at sheath-to-sample flow ratios of $10: 1$. The resulting monodisperse particles were exposed to a predefined RH environment using two Nafion membrane tubes (Permapure Inc. model MD-110-12S-4) in series. The target RH, which was set at $90 \%$, was regulated by controlling the flow ratio of humidified and dry airflows via PID controlling software (LabVIEW, National Instruments Inc.). The particle residence time between the humidifier and the second DMA was approximately $10 \mathrm{~s}$. The RH-controlled humid air was used as the sheath flow for the second DMA. The RH and temperature of the second DMA were continuously monitored at both the sample inlet and sheath outlet using two capacitive RH and temperature probes (Rotronic Inc. Hygroclip HC2-S). The RH differences between the sample and sheath flows were less than $2 \%$. RH of humidified sample air was slightly higher than that of the sheath outflow for the setup shown in Fig. S1.

The operating conditions of the DMAs were checked using $100 \pm 3 \mathrm{~nm}$ polystyrene latex particles (PSL, Thermo Scientific Inc., cat. no. 3100A). Hygroscopic growth of particles in the HTDMA was calibrated by measuring growth factor $(g)$, which is defined as a diameter ratio of humidified $(D(\mathrm{RH}))$ and dry particles $\left(D_{0}\right)\left(g=\left(D(\mathrm{RH}) / D_{0}\right)\right.$, of ammonium sulfate particles. The measured value of $g$ at $\mathrm{RH}=85 \%$ was $1.71\left(D_{0}=150 \mathrm{~nm}\right)$, which is comparable to literature data ( $g=1.69)$ (Tang and Munkelwitz, 1994). The stability of detected RH of the HTDMA system was within $\pm 1.0 \% \mathrm{RH}$ (peak to peak) for the target RH of $90 \%$ (see Fig. S2). A volume mean growth factor (GF) was calculated using measured probability density function of $g$ (i.e., $c\left(g, D_{0}\right)$ ) as $\mathrm{GF}=\left(\int_{0}^{\infty} g^{3} c\left(g, D_{0}\right) d g\right)^{1 / 3}$.

\subsection{Chemical characterization}

The Aerodyne ToF-ACSM was utilized to measure chemical compositions of non-refractory submicron particles (NR$\mathrm{PM}_{1}$ ) (Fröhlich et al., 2013). Five specific chemical components - including organic matter $(\mathrm{OM})$, sulfate $\left(\mathrm{SO}_{4}^{2-}\right)$, nitrate $\left(\mathrm{NO}_{3}^{-}\right)$, ammonium $\left(\mathrm{NH}_{4}^{+}\right)$, and chloride $\left(\mathrm{Cl}^{-}\right)$- were 
quantitatively detected (Allan et al., 2003), with a time resolution of 3 min.

Bulk OC, elemental carbon (EC), and WSOC contents were also analyzed for 10 samples (Table 3) using quartzfiber filter samples ( $47 \mathrm{~mm}$ in diameter). All the quartz-fiber filters were prebaked at $900^{\circ} \mathrm{C}$ for $3 \mathrm{~h}$ before sampling. The filter samples were stored in a refrigerator $\left(-20^{\circ} \mathrm{C}\right)$ until analysis. For each sampling, a backup quartz-fiber filter was used to account for potential influence of adsorption of gas phase organic components (Turpin et al., 1994). OC loading on the backup filter was subtracted from that on the front filter to estimate particulate OC (i.e., corrected OC).

$\mathrm{OC}$ and $\mathrm{EC}$ were analyzed by thermal-optical reflectance analysis (Chow et al., 1993) using a Sunset Laboratory OCEC analyzer, following the IMPROVE-A protocol. WSOC was quantified with a Sievers 800 total organic carbon (TOC) analyzer after extraction of biomass burning filter samples by water. A portion $(8 \mathrm{~mm} \varphi)$ of each WSOC sample was extracted using $10 \mathrm{~mL}$ of HPLC-grade water. The samples were shaken by an orbital shaker for $21 \mathrm{~h}$. The extracted sample solutions were filtered with syringe filters (pore size of $0.2 \mu \mathrm{m}$ ) prior to injection to the TOC analyzer. The particulate WSOC of peat burning particles was also corrected following a similar procedure to that of particulate OC.

\section{Results and discussion}

Both the HTDMA and chemical analysis data are summarized in Tables 2 and 3. The ToF-ACSM and OC-EC data (Table 3) demonstrate that chemical composition of submicron biomass burning particles is dominated by organic species, accounting for approximately $99 \%$ in mass (Budisulistiorini et al., 2017). Contributions of other species, including inorganic ionic species and EC, were minimal. In the following, the relationships between hygroscopic properties and chemical characteristics of organic species are discussed.

\subsection{Hygroscopic growth factor}

Figure 2 shows normalized particle number size distributions of peat sampled from a burnt area (Riau-4), acacia leaves, and fern burning particles following hygroscopic growth at $\mathrm{RH}=90 \%\left(D_{0}=100 \mathrm{~nm}\right)$. The data shown in Fig. 2 include both online (a) and offline (b: $A_{0} ; \mathrm{c}: A_{1}$ ) measurements. In all cases, narrow monodisperse distributions were observed (see Fig. S3), demonstrating that chemical compositions of particles were uniform (Gysel et al., 2007; Carrico et al., 2010). For online measurements, diameter change induced by hygroscopic growth was minimal for the peat and acacia burning particles ( $g=1.05-1.09$ ), while diameter of fern burning particles significantly increased following exposure to high $\mathrm{RH}(g=1.17)$. The variation in hygroscopic properties is attributed to differences in organic chemical composition, as
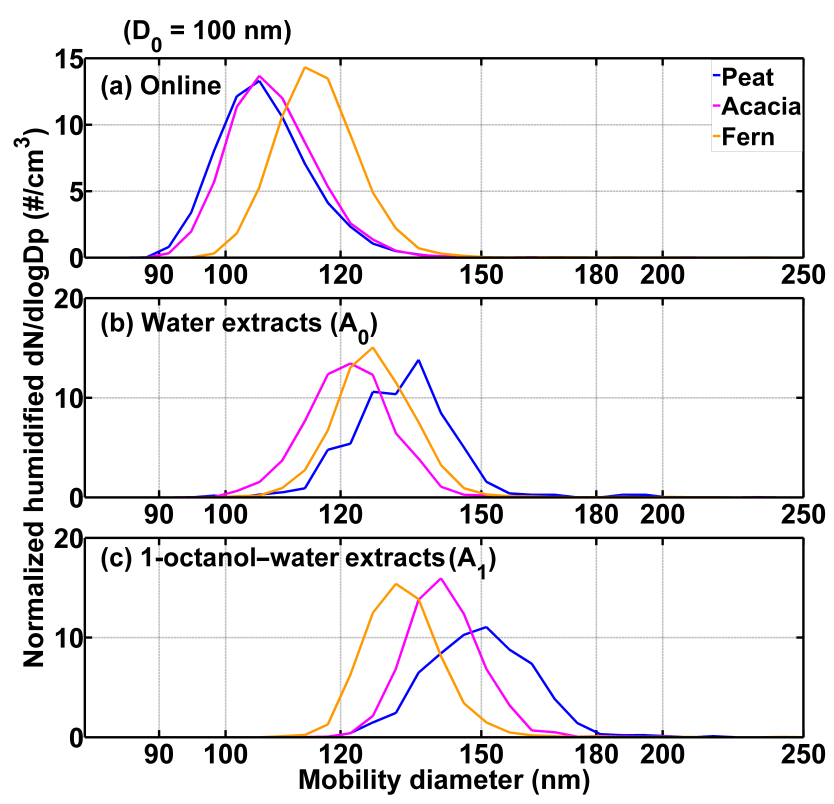

Figure 2. Normalized number size distributions measured by the HTDMA $\left(D_{0}=100 \mathrm{~nm} ; \mathrm{RH}=90 \%\right)$ of peat, fern, and acacia burning particles. (a) Online data, (b) $A_{0}$, and (c) $A_{1}$. For online data, peat burning particles are nearly non-hygroscopic, while fern burning particles are more hygroscopic. Aqueous extracts of peat burning particles are the most hygroscopic among the three types of biomasses. The $x$ axis is on a logarithmic scale.

these biomass burning particles contain negligible fractions of inorganic ionic species (Budisulistiorini et al., 2017).

Table 2 summarizes all the values of GF. Values of GF for most of peat samples from burnt peatland in Riau were less than 1.1. Sampling depths of peat did not significantly affect GF. There was no clear size dependence of GF. For instance, GF values of particles from combustion of peat at drained and burnt areas in Riau were $1.07 \pm 0.04\left(D_{0}=\right.$ $50 \mathrm{~nm}), 1.06 \pm 0.02\left(D_{0}=100 \mathrm{~nm}\right)$, and $1.07 \pm 0.02\left(D_{0}=\right.$ $200 \mathrm{~nm}$ ). Particles emitted from the undisturbed forest area in Riau (i.e., Riau-Zam) were more hygroscopic $(\mathrm{GF}=1.11$ for $D_{0}=100 \mathrm{~nm}$ ) than those generated from other samples from Riau, while GF of particles emitted by combustion of a peat sample from the secondary forest in Riau (i.e., RiauSF) was very similar to those from Riau peat samples from burnt areas (i.e., Riau-1-4). The similarity is probably due to the short distance between the two sampling sites (less than $10 \mathrm{~km}$ ). Particles emitted from peat samples collected in Central Kalimantan (i.e., C.K.-DB and C.K.-DF) were relatively more hygroscopic $(\mathrm{GF}>1.11)$ than those from Riau.

Hygroscopic growth of the bulk water-soluble fraction $\left(A_{0}\right)$ is much more significant than that of the online measurements. Specifically, the mean diameter growth factors were 1.34 (peat sampled from a burnt area, Riau-4), 1.23 (acacia), and 1.28 (fern) for $100 \mathrm{~nm}$ particles. The significant hygroscopic growth of $A_{0}$ from peat burning particles 
Table 2. Volume weighted mean GF and $\kappa$ values (average \pm 1 standard deviation, SD) of different types of Indonesian peat and biomasses. The results of their aqueous extracts $\left(A_{0}\right.$ and $\left.A_{1}\right)$ are also shown.

\begin{tabular}{|c|c|c|c|c|c|c|c|c|}
\hline & \multicolumn{2}{|c|}{ Sample name } & \multicolumn{3}{|c|}{ Mean GF $(\mathrm{RH}=90 \%)$} & \multicolumn{3}{|c|}{ Mean $\kappa(\mathrm{RH}=90 \%)$} \\
\hline \multirow{11}{*}{$\stackrel{\mathscr{\Xi}}{\Xi}$} & \multirow[t]{7}{*}{ Sumatra } & Riau-1 & $1.17 \pm 0.07$ & $1.09 \pm 0.06$ & $1.04 \pm 0.01$ & $0.089 \pm 0.042$ & $0.039 \pm 0.028$ & $0.016 \pm 0.002$ \\
\hline & & Riau-1.2 & $1.00 \pm 0.002$ & $1.08 \pm 0.04$ & $1.06 \pm 0.01$ & $0.001 \pm 0.001$ & $0.036 \pm 0.017$ & $0.025 \pm 0.002$ \\
\hline & & Riau-2 & - & $1.07 \pm 0.01$ & $1.12 \pm 0.06$ & - & $0.029 \pm 0.005$ & $0.052 \pm 0.032$ \\
\hline & & Riau-2.1 & $1.06 \pm 0.04$ & $1.06 \pm 0.01$ & $1.06 \pm 0.01$ & $0.029 \pm 0.019$ & $0.023 \pm 0.005$ & $0.024 \pm 0.005$ \\
\hline & & Riau-3.1 & $1.05 \pm 0.02$ & $1.05 \pm 0.02$ & $1.08 \pm 0.01$ & $0.024 \pm 0.012$ & $0.022 \pm 0.010$ & $0.031 \pm 0.006$ \\
\hline & & Riau-4 & $1.04 \pm 0.01$ & $1.08 \pm 0.01$ & $1.05 \pm 0.002$ & $0.017 \pm 0.003$ & $0.034 \pm 0.003$ & $0.019 \pm 0.001$ \\
\hline & & Riau-4.1 & $1.07 \pm 0.10$ & $0.99 \pm 0.01$ & $1.02 \pm 0.01$ & $0.059 \pm 0.063$ & $\mathrm{n} / \mathrm{a}$ & $0.007 \pm 0.003$ \\
\hline & (Burnt peatland) & Riau D\&B ${ }^{b}$ & $1.07 \pm 0.04$ & $1.06 \pm 0.02$ & $1.07 \pm 0.02$ & $0.040 \pm 0.023$ & $0.029 \pm 0.010$ & $0.026 \pm 0.007$ \\
\hline & (Secondary forest) & Riau-SF & $1.04 \pm 0.05$ & $1.07 \pm 0.004$ & $1.09 \pm 0.01$ & $0.025 \pm 0.028$ & $0.028 \pm 0.002$ & $0.034 \pm 0.003$ \\
\hline & \multirow{2}{*}{ Kalimantan } & Acacia & $1.05 \pm 0.01$ & $1.09 \pm 0.01$ & $1.09 \pm 0.01$ & $0.026 \pm 0.005$ & $0.039 \pm 0.006$ & $0.037 \pm 0.006$ \\
\hline & & Fern & $1.08 \pm 0.02$ & $1.17 \pm 0.02$ & $1.20 \pm 0.03$ & $0.039 \pm 0.011$ & $0.078 \pm 0.010$ & $0.088 \pm 0.014$ \\
\hline \multicolumn{9}{|c|}{ Aqueous extracts: $A_{0}$ (the water extracts), $A_{1}$ (the 1-octanol-water extracts) } \\
\hline \multirow{6}{*}{$\underset{O}{\stackrel{g}{\Xi}}$} & \multirow{3}{*}{$A_{0}$} & Peat $^{\mathrm{a}}$ & $1.29 \pm 0.05$ & $1.34 \pm 0.06$ & $1.38 \pm 0.09$ & $0.168 \pm 0.039$ & $0.179 \pm 0.038$ & $0.198 \pm 0.058$ \\
\hline & & Acacia & $1.17 \pm 0.03$ & $1.23 \pm 0.04$ & $1.28 \pm 0.05$ & $0.090 \pm 0.019$ & $0.110 \pm 0.025$ & $0.135 \pm 0.027$ \\
\hline & & Fern & $1.18 \pm 0.03$ & $1.28 \pm 0.03$ & $1.32 \pm 0.05$ & $0.100 \pm 0.016$ & $0.141 \pm 0.020$ & $0.157 \pm 0.031$ \\
\hline & \multirow{3}{*}{$A_{1}$} & Peat $^{\mathrm{a}}$ & $1.47 \pm 0.06$ & $1.50 \pm 0.09$ & $1.47 \pm 0.11$ & $0.311 \pm 0.052$ & $0.302 \pm 0.074$ & $0.262 \pm 0.083$ \\
\hline & & Acacia & $1.32 \pm 0.04$ & $1.42 \pm 0.03$ & $1.44 \pm 0.07$ & $0.195 \pm 0.027$ & $0.237 \pm 0.023$ & $0.239 \pm 0.049$ \\
\hline & & Fern & $1.28 \pm 0.04$ & $1.33 \pm 0.05$ & $1.39 \pm 0.05$ & $0.162 \pm 0.026$ & $0.177 \pm 0.034$ & $0.205 \pm 0.038$ \\
\hline
\end{tabular}

- Data are unavailable due to low particle number concentration.
a Riau D\&B represents the averages of all the D\&B peat samples collected from different depths of the Sumatran peatlands (i.e., samples used for Exp. 1-10 in Table 1).

b Peat in Table 2 refers to the Riau-4 sample collected from burnt peatlands in Sumatra (see Sect. 2 for details).

could be due to high water uptake by the highly water-soluble fraction, $A_{1}(\mathrm{GF}=1.50)$. The $\mathrm{GFs}$ of $A_{1}$ for acacia and fern burning particles were 1.42 and 1.33 , respectively. Although water uptake by fresh peat burning particles was much less than that of vegetation burning particles, the water-soluble fraction of peat burning particles was the most hygroscopic. This result stresses the importance of understanding hygroscopic properties of WSOM as well as the WSOC fraction in total OC.

\subsection{Hygroscopicity parameter $(\kappa)$}

Hygroscopicity parameter $(\kappa)$ was calculated using the $\kappa-$ Köhler theory (Petters and Kreidenweis, 2007):

$\kappa=\left(\mathrm{GF}^{3}-1\right) \cdot\left(\frac{\exp \left(\frac{4 \sigma_{\mathrm{S} / \mathrm{a}} \cdot M_{\mathrm{w}}}{\rho_{\mathrm{w}} \cdot R \cdot T \cdot D_{0} \cdot \mathrm{GF}}\right)}{\mathrm{RH}}-1\right)$,

where $\sigma_{\mathrm{s} / \mathrm{a}}$ is the surface tension of the solution-air interface $\left(0.0718 \mathrm{~N} \mathrm{~m}^{-1}\right.$ at $\left.25^{\circ} \mathrm{C}\right), M_{\mathrm{w}}$ is the molecular weight of water $\left(18 \mathrm{~g} \mathrm{~mol}^{-1}\right), \rho_{\mathrm{w}}$ is the density of water $\left(1.0 \mathrm{~g} \mathrm{~cm}^{-3}\right), R$ is the universal gas constant $\left(8.31 \mathrm{JK}^{-1} \mathrm{~mol}^{-1}\right)$, and $T$ is tem- perature $(298 \mathrm{~K})$. The calculated $\kappa$ results for our HTDMA measurements are summarized in Fig. 3 and Table 2. It is worth noting that $\kappa$ is related to the molar volume of watersoluble compounds $\left(M_{\mathrm{S}} / \rho_{\mathrm{s}}\right)$, which is calculated from both the molecular weight $\left(M_{\mathrm{S}}\right)$ and density $\left(\rho_{\mathrm{s}}\right)$ by the following equation (Rose et al., 2008):

$\kappa=i_{\mathrm{s}} \frac{\rho_{\mathrm{s}} M_{\mathrm{w}}}{\rho_{\mathrm{w}} M_{\mathrm{s}}}$,

where $i$ is the van't Hoff factor. Eq. (2) was mainly employed to derive $\kappa$ from the experimental data of Asa-Awuku et al. (2008), who calculated the mean molar volume of WSOM extracted from biomass burning particles with a $\mathrm{CCN}$ measurement.

The range of $\kappa$ for peat burning particles in Riau (sampled from burnt areas) is 0.02 to 0.04 , while that for Central Kalimantan samples is 0.05 to $0.06(100 \mathrm{~nm})$. These values may be compared with CCN activity of peat burning particles reported by Dusek et al. (2005). Based on the experimental data by Dusek et al. (2005), the critical supersaturation for CCN activation of Indonesian peat burning particles is derived as $0.53 \%$ for $100 \mathrm{~nm}$ particles. This value can be converted to 
Table 3. Summary of chemical characteristics of different types of Indonesian peat and biomass burning particles.

\begin{tabular}{|c|c|c|c|c|c|c|c|}
\hline \multicolumn{2}{|c|}{ Sample name } & $\begin{array}{r}\text { Mean } \kappa \\
(100 \mathrm{~nm})\end{array}$ & $\frac{f_{44}}{(\%)}$ & $\frac{f_{\mathrm{HMW}}}{(\%)}$ & $\frac{\mathrm{OC}}{(\mathrm{mg} \mathrm{C})}$ & $\frac{\mathrm{EC}}{(\mathrm{mg} \mathrm{C})}$ & $\frac{\text { WSOC / OC }}{(\%)}$ \\
\hline \multirow[t]{6}{*}{ Sumatra } & Riau-1 & 0.039 & 0.4 & 42.9 & 12.69 & 0.13 & 0.93 \\
\hline & Riau-2 & 0.029 & 0.7 & 26.9 & 14.08 & 0.12 & 1.80 \\
\hline & Riau-3 & 0.022 & 0.7 & 31.7 & 13.58 & 0.13 & 1.63 \\
\hline & Riau-4 & 0.034 & 0.5 & 29.0 & 18.86 & 0.13 & 1.51 \\
\hline & Riau-SF & 0.028 & 1.7 & 21.1 & 7.64 & 0.07 & 4.15 \\
\hline & Riau-Zam & 0.048 & 1.6 & 23.8 & 2.58 & 0.03 & 6.08 \\
\hline \multirow[t]{4}{*}{ Kalimantan } & C.K.-DF & 0.058 & 2.0 & 19.5 & 5.58 & 0.05 & 4.16 \\
\hline & C.K.-DB & 0.054 & 1.9 & 19.3 & 7.51 & 0.05 & 2.03 \\
\hline & Acacia & 0.039 & 1.1 & 27.0 & 14.61 & 0.05 & 3.42 \\
\hline & Fern & 0.078 & 1.9 & 21.5 & 13.34 & 0.07 & 6.56 \\
\hline \multirow{3}{*}{$A_{0}$} & Peat $^{\mathrm{a}}$ & 0.179 & 9.5 & 15.8 & $\mathrm{n} / \mathrm{a}$ & $\mathrm{n} / \mathrm{a}$ & $\mathrm{n} / \mathrm{a}$ \\
\hline & Acacia & 0.110 & 4.7 & 21.8 & $\mathrm{n} / \mathrm{a}$ & $\mathrm{n} / \mathrm{a}$ & $\mathrm{n} / \mathrm{a}$ \\
\hline & Fern & 0.141 & 5.2 & 17.4 & $\mathrm{n} / \mathrm{a}$ & $\mathrm{n} / \mathrm{a}$ & $\mathrm{n} / \mathrm{a}$ \\
\hline \multirow{3}{*}{$A_{1}$} & Peat $^{\mathrm{a}}$ & 0.302 & 9.3 & 16.0 & $\mathrm{n} / \mathrm{a}$ & $\mathrm{n} / \mathrm{a}$ & $\mathrm{n} / \mathrm{a}$ \\
\hline & Acacia & 0.237 & 6.6 & 11.6 & $\mathrm{n} / \mathrm{a}$ & $\mathrm{n} / \mathrm{a}$ & $\mathrm{n} / \mathrm{a}$ \\
\hline & Fern & 0.177 & 7.9 & 8.2 & $\mathrm{n} / \mathrm{a}$ & $\mathrm{n} / \mathrm{a}$ & $\mathrm{n} / \mathrm{a}$ \\
\hline
\end{tabular}

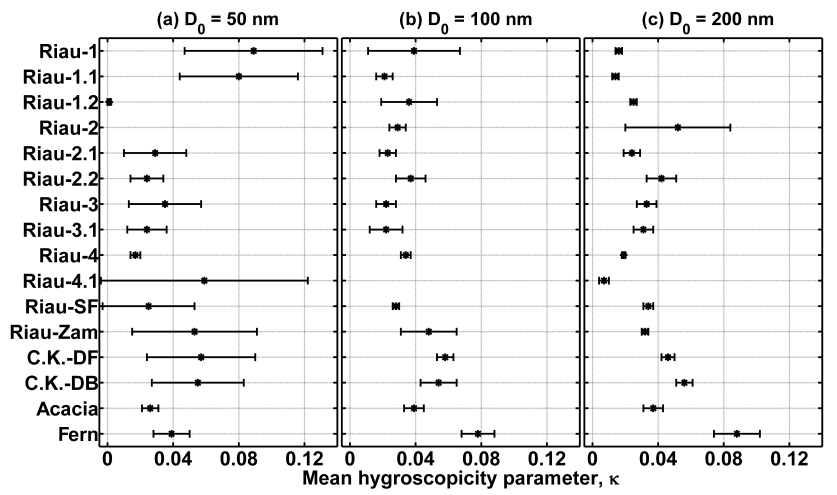

Figure 3. Mean $\kappa$ values of fresh Indonesian biomass burning particles measured for (a) $D_{0}=50 \mathrm{~nm}$, (b) $D_{0}=100 \mathrm{~nm}$, and (c) $D_{0}=$ $200 \mathrm{~nm}$ particles. In all cases, $\kappa$ values are lower than 0.1 . The largest $\kappa$ values were measured for fern burning particles $\left(D_{0}=\right.$ $100 \mathrm{~nm}$ and $D_{0}=200 \mathrm{~nm}$ ). Particles emitted from combustion of peat in Central Kalimantan are generally more hygroscopic than those from Riau, Sumatra. Error bars denote the corresponding standard deviations.

$\kappa$ of 0.05 , which is very similar to the values summarized in Fig. 3 and Table 2. The consistently low values of $\kappa$ suggest that water uptake by freshly emitted peat burning particles is minimal. The range of $\kappa$ observed for acacia and fern burning particles $(\kappa=0.04-0.08)$ is comparable to that observed for a less hygroscopic mode by previous laboratory experiments on biomass burning particles (Carrico et al., 2010).

The values of $\kappa$ observed for water extracts $\left(A_{0}\right)$ span from 0.11 (acacia, $100 \mathrm{~nm}$ ) to 0.18 (peat sampled from a burnt

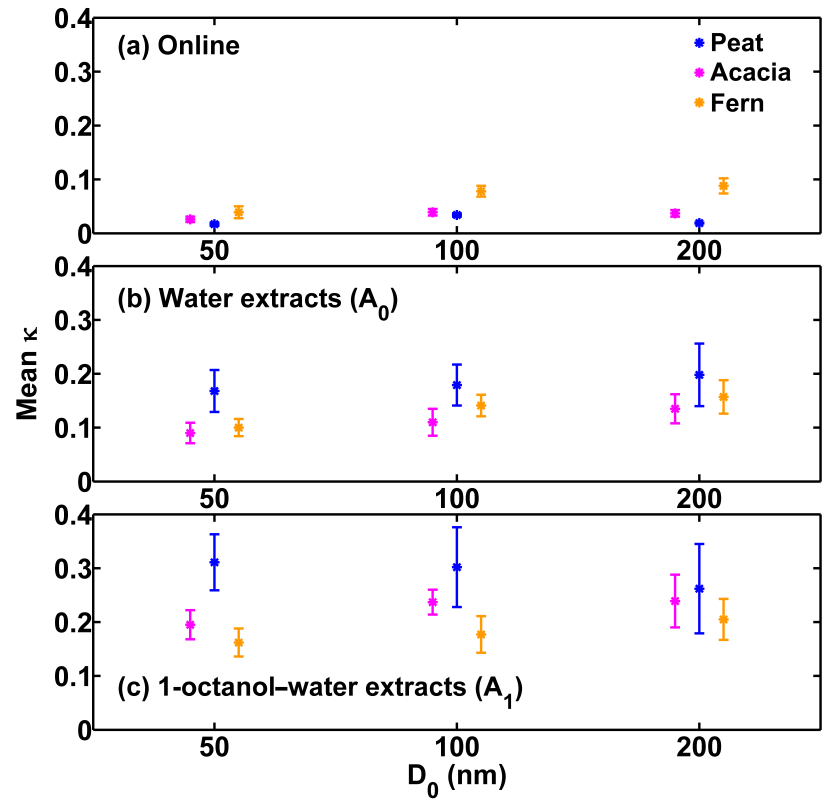

Figure 4. Comparison of $\kappa$ values for (a) online, (b) water extracts $\left(A_{0}\right)$, and (c) 1-octanol-water extracts $\left(A_{1}\right)$. The data for peat (Riau-4), acacia, and fern are shown. Indonesian peat burning particles are almost non-hygroscopic for online data, while their watersoluble organic fractions are highly hygroscopic.

area, Riau-4, $100 \mathrm{~nm}$ ) (Fig. 4 and Table 2). The $\kappa$ value for peat burning particles $\left(A_{0}\right)$ is significantly higher than those emitted from the acacia and fern leaves, highlighting the importance of understanding hygroscopicity of the WSOM as 
well as the water-soluble fraction in order to quantitatively understand water uptake properties. The value of $\kappa$ for acacia burning particles is similar to what was measured for WSOM extracted from a prescribed forest fire experiment in Georgia (USA) $(\kappa=0.10)$, which was estimated using a molar volume of $1.6 \times 10^{-4} \mathrm{~m}^{3} \mathrm{~mol}^{-1}$ (Asa-Awuku et al., 2008).

The $\kappa$ values for $A_{1}$ are higher than those for $A_{0}$. Namely, $\kappa$ values observed for $A_{1}$ were 0.30 (peat sampled from a burnt area, Riau-4), 0.24 (acacia), and 0.18 (fern). Although it is the first hygroscopic measurement for WSOM classified with the 1-octanol-water liquid-liquid extraction technique, the value could be compared with those for hydrophilic fractions classified by the XAD-8 column. Kuwata and Lee (2017) demonstrated that classification of WSOM by the XAD-8 column, which is one of the most frequently used materials for solid-phase extraction of WSOM, has a strong relationship with the 1-octanol-water partitioning coefficient $\left(K_{\text {OW }}\right)$. Namely, the XAD-8 column selectively traps hydrophobic chemical species in WSOM, which tend to partition to the 1-octanol phase $\left(K_{\mathrm{OW}}>1\right)$. Thus, the hydrophilic fraction separated by XAD-8 is dominantly composed of chemical species with $K_{\mathrm{OW}}<1$. The WSOM in $A_{1}$ is also dominantly composed of organic compounds with lower values of $K_{\mathrm{OW}}\left(K_{\mathrm{OW}}<1\right)$, suggesting that $A_{1}$ and WSOM classified by XAD- 8 are comparable. The $\kappa$ value of biomass burning WSOM separated by XAD-8 is estimated as 0.29 , using molar volume $\left(6.2 \times 10^{-5} \mathrm{~m}^{3} \mathrm{~mol}^{-1}\right)$ estimated from a CCN measurement by Asa-Awuku et al. (2008). The comparison provides a typical range of $\kappa$ for the hydrophilic $\left(K_{\mathrm{OW}}<1\right)$ fraction of WSOM emitted from biomass burning as $0.2-0.3$. Our results of water uptake by organic compounds (e.g., bulk organic material, bulk WSOM, and highly hydrophilic WSOM) could be further employed to verify a theoretical framework which uses distributions of water solubility as input parameters (Riipinen et al., 2015).

\section{$3.3 \kappa$ (online) and WSOC / OC}

WSOC / OC ratios of Indonesian peat and vegetation burning particles are summarized in Table 3. In general, WSOC / OC ratios for peat burning particles from the burnt area in Riau are small, ranging from 0.93 to $1.80 \%$. Particles emitted from combustion of peat collected in other areas tend to contain higher fractions of WSOC (WSOC / OC $=2.03-$ $6.08 \%$ ). The variability in WSOC / OC ratios could be due to differences in chemical composition of peat sampled at different areas (Hikmatullah and Sukarman, 2014). These values are an order of magnitude lower than the experimental data by linuma et al. (2007), which reported WSOC / OC ratios for Indonesian peat burning particles from South Sumatra as $39 \%$. The significant difference in WSOC / OC ratios could stem from the variations in chemical compositions of peat as well as combustion conditions. Both a systematic laboratory experiment and chemical analysis of freshly emitted peat burning particles are needed to address the difference

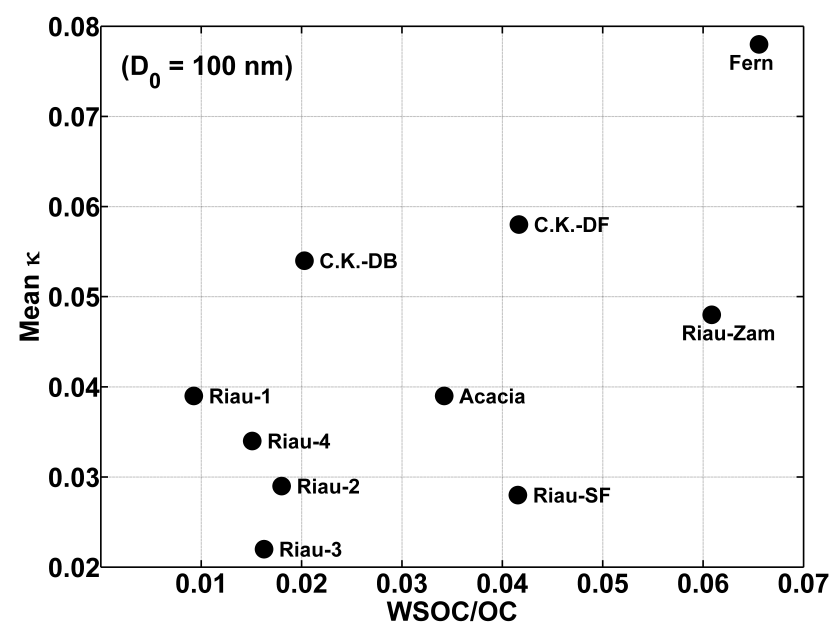

Figure 5. Correlation of $\kappa$ and WSOC / OC ratios for different types of Indonesian peat and biomasses.

in the data. The WSOC fractions for acacia and fern burning particles were relatively higher (WSOC / OC $=3.42-$ $6.56 \%$ ) than those from peat combustion.

Figure 5 compares $\kappa$ and WSOC/OC ratios. $\kappa$ and WSOC / OC correlate to some extent $(R=0.65)$, although the variation ranges for both variables are small. Fern burning particles contain a significantly higher fraction of WSOM than other samples, providing an explanation for the higher $\kappa$ value for fern burning particles. Nevertheless, the correlation between these two parameters is not tight. This result suggests that other factors, such as chemical composition and hygroscopic properties of the water-soluble fraction, should also be considered to quantitatively understand water uptake properties.

\section{$3.4 \kappa$ and $\mathrm{OM}$ mass spectra}

Figure 6 shows the ToF-ACSM mass spectra for online, $A_{0}$, and $A_{1}$ particles, including those from peat (sampled at a burnt area, Riau-4), acacia, and fern burning. The online mass spectra have intense signals at $m / z, 41\left(\mathrm{C}_{3} \mathrm{H}_{5}^{+}\right), 43$ (most likely $\left.\mathrm{C}_{3} \mathrm{H}_{7}^{+}\right), 55\left(\mathrm{C}_{4} \mathrm{H}_{7}^{+}\right)$, and $57\left(\mathrm{C}_{4} \mathrm{H}_{9}^{+}\right)$, suggesting that these particles are highly hydrogenated (Canagaratna et al., 2015). On the other hand, fractions of ions at $m / z 44\left(f_{44}\right.$, mostly $\left.\mathrm{CO}_{2}^{+}\right)$are limited $\left(f_{44}<0.02\right)$, especially for peat burning particles. This result signifies that the freshly emitted Indonesian biomass burning particles, especially those from peat, are not highly oxygenated ( $\mathrm{Ng}$ et al., 2011). This is in accordance with a previous study, which showed that $f_{44}$ values for primary hydrocarbon-like organic compounds are usually less than 0.05 ( $\mathrm{Ng}$ et al., 2011). In addition, $m / z 60$ and 73 (mainly from $\mathrm{C}_{2} \mathrm{H}_{4} \mathrm{O}_{2}^{+}$and $\mathrm{C}_{3} \mathrm{H}_{5} \mathrm{O}_{2}^{+}$, respectively), marker ions of levoglucosan-like species (a tracer for cellulose in biomass burning particles) (Simoneit et al., 1999; 


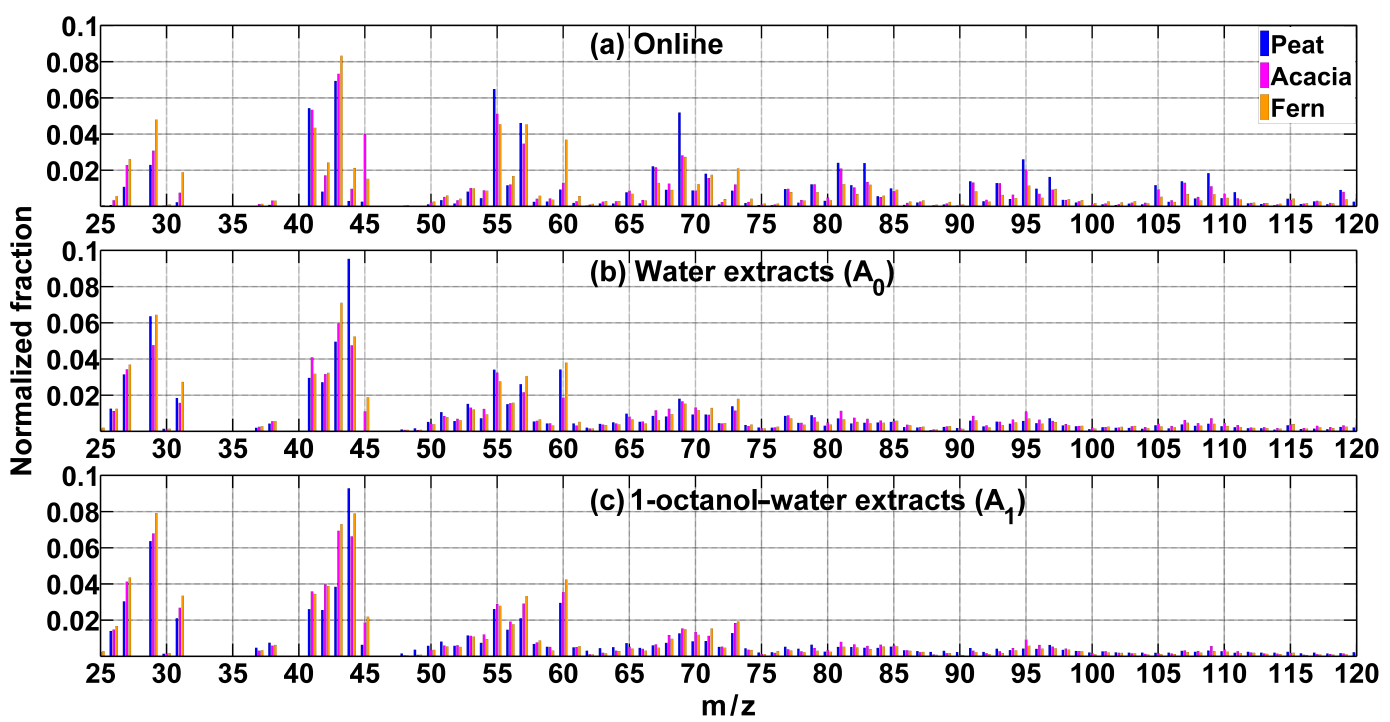

Figure 6. Mass spectra of organics in Indonesian biomass burning particles measured for peat, acacia, and fern samples. (a) Online, (b) $A_{0}$, and (c) $A_{1}$ data are shown. Ion signals $(\mathrm{m} / z)$ from hydrocarbon-like organic compounds (e.g., $\left.m / z, 41,43,55,57\right)$ are prominent for online data, while intensities of ions for oxygenated organics (e.g., $m / z 44)$ and biomass burning tracers (e.g., $m / z$ 60, 73) are relatively less intense. On the other hand, both $\mathrm{m} / z, 44$ and $\mathrm{m} / z, 60$ signals are significant for mass spectra of $A_{0}$ and $A_{1}$. See the text for details.

Cubison et al., 2011), were especially pronounced for fern burning particles.

The mass spectra of $A_{0}$ are significantly different from those of online measurements. The most abundant ion in the mass spectra of $A_{0}$ is $m / z$ 44. Hydrocarbon peaks - such as $m / z 41,43,55$, and 57 - are still significant, yet they are less abundant than those of the online measurements. In addition, contributions of $m / z 60$ and 73 are also enhanced. These results consistently support the idea that the $A_{0}$ fraction is highly oxygenated. Especially, the $A_{0}$ fraction for peat burning particles is much more oxidized than those of fern and acacia samples.

The mass spectra of $A_{1}$ from acacia and fern burning show that the $A_{1}$ fraction is more oxidized than $A_{0}$, as indicated by higher values of $f_{44}$. For instance, $f_{44}$ of $A_{1}$ from fern burning particles is 0.08 , while that of $A_{0}$ is 0.05 . Another notable characteristic of $A_{1}$ mass spectra is the smaller fraction of high-molecular-weight (HMW) ions, which is observed for the region of $m / z>100$. The HMW fractions $\left(f_{\mathrm{HMW}}\right)$ for $A_{0}$ and $A_{1}$ are 15.8 and $16.0 \%$ (peat sampled at a burnt area, Riau-4), 21.8 and $11.6 \%$ (acacia), and 17.4 and $8.2 \%$ (fern), which are significantly lower than the corresponding values for online measurements (Table 3). These results suggest that $A_{1}$ contains lower fractions of high-molecular-weight species, although decomposition during ionization process makes the estimation of actual contributions of these compounds difficult.

Figure 7 displays $f_{44}, f_{60}$, and mean $\kappa$ for different types of Indonesian biomass burning particles. The data points in Fig. 7 distribute to two different regions. Low $f_{44}$ and $f_{60}$ values are observed for particles emitted from Sumatran peat

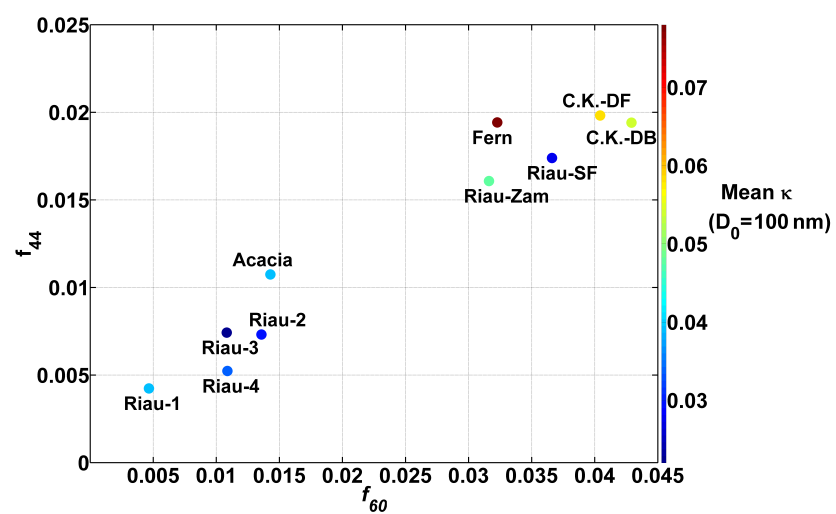

Figure 7. Correlation of $f_{44}$ and $f_{60}$ for different types of Indonesian peat and biomasses.

burning (i.e., Riau-1, -2, -3, -4). The $f_{44}$ of acacia burning particles is slightly higher, but $f_{60}$ is low. By contrast, distinctly higher $f_{44}$ and $f_{60}$ are observed for fern, undisturbed peat (Riau), and peat (Central Kalimantan) burning particles. This is also in accordance with the proton nuclear magnetic resonance $\left({ }^{1} \mathrm{H}\right.$ NMR) analysis, which suggests that functional-group distributions of peat and acacia burning particles are significantly different from those emitted from fern burning particles. Namely, the peat and acacia samples contain a significantly higher fraction of the saturated aliphatic group (i.e., $\mathrm{H}-\mathrm{C} ; 71.7 \%$ for peat, and $64.0 \%$ for acacia) than the fern sample (38.6\%; see Fig. S4a), which readily prohibits the bulk hygroscopic growth of fresh peat burning particles. Besides, the highly polar structure (i.e., $\mathrm{H}-\mathrm{C}-\mathrm{O}$ ) in the 


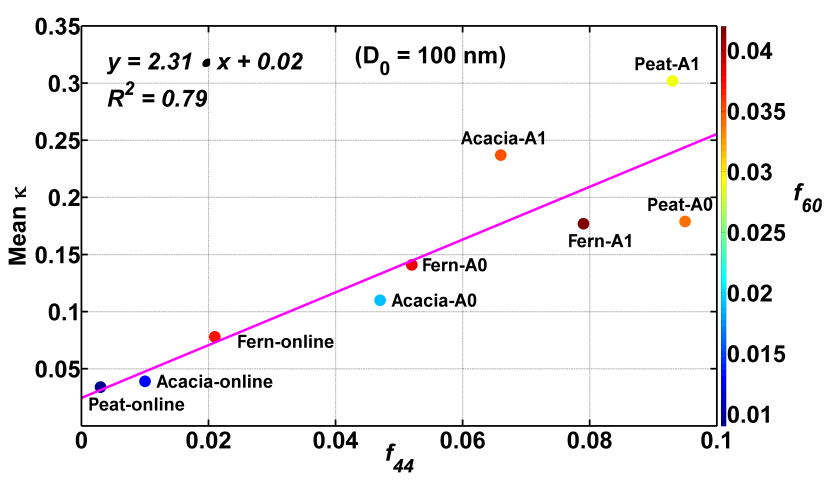

Figure 8. Correlation of $\kappa$ and $f_{44}$. The magenta line shows the result of fitting by the least-squares method.

peat $(6.0 \%)$ and acacia $(8.1 \%)$ samples is distinctly lower than that in the fern sample $(15.5 \%$, Fig. S4a). This likely contributes to the higher WSOC fraction of fern burning particles, and the corresponding higher $\kappa$ values could be related to the higher $f_{44}$ and $f_{60}$.

Figure 8 shows a correlation of $\kappa$ with $f_{44}$ for both online (i.e., bulk organic matter) and offline (i.e., bulk WSOM and highly hydrophilic WSOM fraction) measurements of peat sampled at a burnt area (Riau-4), as well as acacia and fern burning particles. Similar correlations for all the biomass burning samples are displayed in Fig. S5 of the Supplement. The correlation of these two variables is represented as $\kappa=2.31 \times f_{44}+0.02(R=0.89)$. The slope is very close to that reported for the relationship between the hygroscopicity of organics $\left(\kappa_{\mathrm{org}}\right)$ and $f_{44}\left(\kappa_{\mathrm{org}}=2.2 \times f_{44}-0.13\right.$; Duplissy et al., 2011). The correlation demonstrates that the degree of oxidation, which is represented by $f_{44}$, is the key controlling parameter in determining hygroscopicity of Indonesian peatland burning particles. As discussed above, $f_{44}$ of peat burning particles (Riau-4) is extremely small (Table 3). Minimal water uptake by peat burning particles (Riau-4) could be associated with a low water-soluble fraction (Table 3), considering that both $\kappa$ and $f_{44}$ for the corresponding $A_{0}$ or $A_{1}$ sample are high. One notable difference in the correlation found in this work from previous studies is the inclusion of a highly soluble fraction in the analysis. Although the $\kappa-f_{44}$ correlations have been related to enhanced water solubility, the relationships among these three parameters (i.e., $\kappa, f_{44}$, and water solubility) have not been shown prior to this study.

The correlation shown in Fig. 8 has a significant divergence, especially at the region for high $f_{44}$ and $\kappa$ values (upper right corner of the figure), suggesting that degree of oxidation is not the only parameter that controls water uptake properties. Especially, comparison of $A_{0}$ and $A_{1}$ for peat burning particles highlights the limitation of correlating $f_{44}$ and $\kappa$. The values of $f_{44}$ for these two fractions are almost the same, while $\kappa$ for $A_{1}$ is significantly higher than that for $A_{0}$. As discussed in Sect. 3.2, the difference of $A_{0}$ and $A_{1}$ could be related to that of hydrophobic and hydrophilic
WSOM separated by XAD-8 (Graber and Rudich, 2006; Sullivan and Weber, 2006). The hydrophobic fraction separated by XAD-8 is typically considered as humic-like substances (HULIS), which has high molecular weight (e.g., fulvic and humic acids; Gysel et al., 2004; Graber and Rudich, 2006; Fan et al., 2013). These results suggest that quantification of HULIS as well as evaluation of their water uptake properties will be important for understanding hygroscopicity of biomass burning particles, including those emitted from Indonesian peatland fires.

The present study demonstrates the importance of watersoluble organic fractions, which include a highly soluble one, in quantifying the hygroscopic growth of freshly emitted biomass burning particles. Addition of these different watersoluble organic fractions could provide an accurate estimation of hygroscopic growth, which is based on a theoretical background. Only size-unresolved bulk chemical data were employed for the present study. However, chemical characteristics of actual atmospheric particles could depend on both particle size and mixing state. These factors would also need to be considered when applying the laboratory data to future studies.

\section{Conclusions}

Hygroscopic growth of freshly emitted Indonesian biomass burning particles was investigated in the laboratory using a humidified tandem differential mobility analyzer $(\mathrm{RH}=90 \%)$. The biomass samples included peat, fern, and acacia leaves collected in Riau and Central Kalimantan in Indonesia. Hygroscopicity was measured for the freshly emitted particles (online), the bulk water-soluble fraction $\left(A_{0}\right)$, and the highly water-soluble fraction (i.e., fraction with lower $K_{\text {OW }}$ values) classified by the 1-octanol-water partitioning method $\left(A_{1}\right)$. Hygroscopicity parameter $\kappa$ was derived from the growth factor data. Chemical compositions of these particles were also quantified using both online and offline techniques.

Hygroscopicity of fresh Indonesian peat burning particles is highly dependent on the origin and condition (e.g., pristine and disturbed) of peat. Particles emitted from combustion of disturbed peat in Riau were nearly non-hygroscopic (mean $\kappa=0.02-0.04$ ), while those from undisturbed areas were more hygroscopic $(\kappa=0.03-0.05)$. Particles emitted from Central Kalimantan peat samples were generally more hygroscopic $(\kappa=0.05-0.06)$ than those from Riau. For biomass samples, acacia burning particles were slightly hygroscopic $(\kappa=0.03-0.04)$, and fern burning particles were the most hygroscopic $(\kappa=0.04-0.09)$ among all samples. These values loosely correlated with the ratio of WSOC to OC $(R=0.65)$. This result suggests that the WSOC fraction could play an important role in determining $\kappa$, yet other factors, such as difference in hygroscopicity of slightly and highly water-soluble fractions, should also be considered. 
Hygroscopicity data of $A_{0}$ and $A_{1}$ fractions were significantly different from those of online measurements. The values of $\kappa$ for $A_{0}$ were $0.17-0.20$ (Riau disturbed peat), $0.09-0.14$ (acacia), and 0.10-0.16 (fern). These values were even higher for $A_{1}(\kappa=0.26-0.31$ for Riau disturbed peat, $\kappa=0.19-0.24$ for acacia, and $\kappa=0.16-0.20$ for fern). These results demonstrate that the low hygroscopicity of Riau peat burning particles (online) is due to the small water-soluble fraction.

The variation in $\kappa$ was related to aerosol mass spectra of organics. $f_{44}$, which is an indicator for degree of oxygenation, correlated well with $\kappa(R=0.89)$, demonstrating that oxygenated functional groups are important for water uptake. In addition, comparison of $A_{0}$ and $A_{1}$ data suggested the importance of high-molecular-weight species, such as humiclike substances, in determining the magnitude of hygroscopicity for water-soluble fractions.

Our experimental results are consistent with previous laboratory studies, which have reported insignificant water uptake by fresh Indonesian peat burning particle (Chand et al., 2005; Dusek et al., 2005). However, Gras et al. (1999) showed that particles observed in a wildfire plume from Kalimantan were hygroscopic. The differences between field observation and laboratory experiments could be caused by atmospheric processes (e.g., secondary formation and chemical aging of particles) and likely resulted from the differences of burnt materials, their origins, and combustion conditions in practical situations as well. In the future, observations of both chemical composition and hygroscopic growth of particles emitted from peatland fires need to be conducted both locally and in downstream regions to address the question. Last but not the least, our results can provide an experimentally validated reference for organics-dominated particle hygroscopicity, thus lowering uncertainties in current climate models and contributing to more accurate estimations of climate impacts caused by Indonesian peatland burning particles on both regional and global scales.

Data availability. The data set for this publication is available upon contacting the corresponding authors.

\section{The Supplement related to this article is available online at https://doi.org/10.5194/acp-17-11591-2017- supplement.}

Competing interests. The authors declare that they have no conflict of interest.

Acknowledgements. This work was supported by the Singapore National Research Foundation (NRF) under its Singapore National Research Fellowship scheme (National Research Fellow Award, NRF2012NRF-NRFF001-031), the Earth Observatory of Singa- pore, and Nanyang Technological University. Masayuki Itoh was funded by the Ministry of Education, Culture, Sports, Science, and Technology for Science Research (15H05625), the Ministry of Environment for Global Environment Research (4-1504), and Research Institute for Humanity and Nature (RIHN), Japan. Takuma Miyakawa and Yuichi Komazaki were supported by the Environment Research and Technology Development Fund (2-1403) of the Ministry of Environment, Japan, and the Japan Society for the Promotion of Science (JSPS), KAKENHI grant number JP26550021. We acknowledge the help of Harris Gunawan and Satomi Shiodera in the collection of some biomass samples in Indonesia. We also thank Gissella B. Lebron for assisting in the laboratory combustion experiments and Pavel Adamek for improving the English writing. The authors are grateful to the editor and two anonymous referees for their insightful comments.

Edited by: Ilona Riipinen

Reviewed by: two anonymous referees

\section{References}

Allan, J. D., Jimenez, J. L., Williams, P. I., Alfarra, M. R., Bower, K. N., Jayne, J. T., Coe, H., and Worsnop, D. R.: Quantitative sampling using an Aerodyne aerosol mass spectrometer 1. Techniques of data interpretation and error analysis, J. Geophys. Res.-Atmos., 108, 4090, https://doi.org/10.1029/2002JD002358, 2003.

Asa-Awuku, A., Sullivan, A. P., Hennigan, C. J., Weber, R. J., and Nenes, A.: Investigation of molar volume and surfactant characteristics of water-soluble organic compounds in biomass burning aerosol, Atmos. Chem. Phys., 8, 799-812, https://doi.org/10.5194/acp-8-799-2008, 2008.

Aswin, U., Hashimoto, Y., Takahashi, H., and Hayasaka, H.: Combustion and thermal characteristics of peat fire in tropical peatland in Central Kalimantan, Indonesia, Tropics, 14, 1-19, 2004.

Bougiatioti, A., Bezantakos, S., Stavroulas, I., Kalivitis, N., Kokkalis, P., Biskos, G., Mihalopoulos, N., Papayannis, A., and Nenes, A.: Biomass-burning impact on $\mathrm{CCN}$ number, hygroscopicity and cloud formation during summertime in the eastern Mediterranean, Atmos. Chem. Phys., 16, 7389-7409, https://doi.org/10.5194/acp-16-7389-2016, 2016.

Budisulistiorini, S. H., Riva, M., Williams, M., Chen, J., Itoh, M., Surratt, J. D., and Kuwata, M.: Light-absorbing brown carbon aerosol constituents from combustion of Indonesian peat and biomass, Environ. Sci. Technol., 51, 4415-4423, 2017.

Canagaratna, M. R., Jimenez, J. L., Kroll, J. H., Chen, Q., Kessler, S. H., Massoli, P., Hildebrandt Ruiz, L., Fortner, E., Williams, L. R., Wilson, K. R., Surratt, J. D., Donahue, N. M., Jayne, J. T., and Worsnop, D. R.: Elemental ratio measurements of organic compounds using aerosol mass spectrometry: characterization, improved calibration, and implications, Atmos. Chem. Phys., 15, 253-272, https://doi.org/10.5194/acp-15-253-2015, 2015.

Carrico, C. M., Petters, M. D., Kreidenweis, S. M., Collett Jr., J. L., Engling, G., and Malm, W. C.: Aerosol hygroscopicity and cloud droplet activation of extracts of filters from biomass burning experiments, J. Geophys. Res.-Atmos., 113, D08206, https://doi.org/10.1029/2007JD009274, 2008. 
Carrico, C. M., Petters, M. D., Kreidenweis, S. M., Sullivan, A. P., McMeeking, G. R., Levin, E. J. T., Engling, G., Malm, W. C., and Collett Jr., J. L.: Water uptake and chemical composition of fresh aerosols generated in open burning of biomass, Atmos. Chem. Phys., 10, 5165-5178, https://doi.org/10.5194/acp10-5165-2010, 2010.

Chan, M. N., Choi, M. Y., Ng, N. L., and Chan, C. K.: Hygroscopicity of Water-Soluble Organic Compounds in Atmospheric Aerosols:? Amino Acids and Biomass Burning Derived Organic Species, Environ. Sci. Technol., 39, 1555-1562, 2005.

Chand, D., Schmid, O., Gwaze, P., Parmar, R. S., Helas, G., Zeromskiene, K., Wiedensohler, A., Massling, A., and Andreae, M. O.: Laboratory measurements of smoke optical properties from the burning of Indonesian peat and other types of biomass, Geophys. Res. Lett., 32, L12819, https://doi.org/10.1029/2005GL022678, 2005.

Chen, Q., Ikemori, F., Higo, H., Asakawa, D., and Mochida, M.: Chemical Structural Characteristics of HULIS and Other Fractionated Organic Matter in Urban Aerosols: Results from Mass Spectral and FT-IR Analysis, Environ. Sci. Technol., 50, 17211730, 2016.

Chow, J. C., Watson, J. G., Pritchett, L. C., Pierson, W. R., Frazier, C. A., and Purcell, R. G.: The DRI Thermal/Optical Reflectance carbon analysis system: Description, evaluation and applications in U.S. air quality studies, Atmos. Environ., 27A, 1185-1201, 1993.

Crippa, P., Castruccio, S., Archer-Nicholls, S., Lebron, G. B., Kuwata, M., Thota, A., Sumin, S., Butt, E., Wiedinmyer, C., and Spracklen, D. V.: Population exposure to hazardous air quality due to the 2015 fires in Equatorial Asia, Sci. Rep., 6, 37074, https://doi.org/10.1038/srep37074, 2016.

Cubison, M. J., Ortega, A. M., Hayes, P. L., Farmer, D. K., Day, D., Lechner, M. J., Brune, W. H., Apel, E., Diskin, G. S., Fisher, J. A., Fuelberg, H. E., Hecobian, A., Knapp, D. J., Mikoviny, T., Riemer, D., Sachse, G. W., Sessions, W., Weber, R. J., Weinheimer, A. J., Wisthaler, A., and Jimenez, J. L.: Effects of aging on organic aerosol from open biomass burning smoke in aircraft and laboratory studies, Atmos. Chem. Phys., 11, 12049-12064, https://doi.org/10.5194/acp-11-12049-2011, 2011.

Day, D. E., Hand, J. L., Carrico, C. M., Engling, G., and Malm, W. C.: Humidification factors from laboratory studies of fresh smoke from biomass fuels, J. Geophys. Res.-Atmos., 111, D22202, https://doi.org/10.1029/2006JD007221, 2006.

Decesari, S., Facchini, M. C., Fuzzi, S., and Tagliavini, E.: Characterization of water-soluble organic compounds in atmospheric aerosol: A new approach, J. Geophys. Res.-Atmos., 105, 14811489, 2000.

Duplissy, J., Gysel, M., Sjogren, S., Meyer, N., Good, N., Kammermann, L., Michaud, V., Weigel, R., Martins dos Santos, S., Gruening, C., Villani, P., Laj, P., Sellegri, K., Metzger, A., McFiggans, G. B., Wehrle, G., Richter, R., Dommen, J., Ristovski, Z., Baltensperger, U., and Weingartner, E.: Intercomparison study of six HTDMAs: results and recommendations, Atmos. Meas. Tech., 2, 363-378, https://doi.org/10.5194/amt-2363-2009, 2009.

Duplissy, J., DeCarlo, P. F., Dommen, J., Alfarra, M. R., Metzger, A., Barmpadimos, I., Prevot, A. S. H., Weingartner, E., Tritscher, T., Gysel, M., Aiken, A. C., Jimenez, J. L., Canagaratna, M. R., Worsnop, D. R., Collins, D. R., Tomlinson, J., and Bal- tensperger, U.: Relating hygroscopicity and composition of organic aerosol particulate matter, Atmos. Chem. Phys., 11, 11551165, https://doi.org/10.5194/acp-11-1155-2011, 2011.

Dusek, U., Frank, G. P., Helas, G., Iinuma, Y., Zeromskiene, K., Gwaze, P., Hennig, T., Massling, A., Schmid, O., Herrmann, H., Wiedensohler, A., and Andreae, M. O.: "Missing" cloud condensation nuclei in peat smoke, Geophys. Res. Lett., 32, L11802, https://doi.org/10.1029/2005GL022473, 2005.

Dusek, U., Frank, G. P., Massling, A., Zeromskiene, K., Iinuma, Y., Schmid, O., Helas, G., Hennig, T., Wiedensohler, A., and Andreae, M. O.: Water uptake by biomass burning aerosol at suband supersaturated conditions: closure studies and implications for the role of organics, Atmos. Chem. Phys., 11, 9519-9532, https://doi.org/10.5194/acp-11-9519-2011, 2011.

Fan, X., Song, J., and Peng, P.: Comparative study for separation of atmospheric humic-like substance (HULIS) by ENVI18, HLB, XAD-8 and DEAE sorbents: Elemental composition, FT-IR, ${ }^{1}$ H NMR and off-line thermochemolysis with tetramethylammonium hydroxide (TMAH), Chemosphere, 93, 1710-1719, 2013.

Fröhlich, R., Cubison, M. J., Slowik, J. G., Bukowiecki, N., Prévôt, A. S. H., Baltensperger, U., Schneider, J., Kimmel, J. R., Gonin, M., Rohner, U., Worsnop, D. R., and Jayne, J. T.: The ToF-ACSM: a portable aerosol chemical speciation monitor with TOFMS detection, Atmos. Meas. Tech., 6, 3225-3241, https://doi.org/10.5194/amt-6-3225-2013, 2013.

Graber, E. R. and Rudich, Y.: Atmospheric HULIS: How humiclike are they? A comprehensive and critical review, Atmos. Chem. Phys., 6, 729-753, https://doi.org/10.5194/acp-6-7292006, 2006.

Gras, J. L., Jensen, J. B., Okada, K., Ikegami, M., Zaizen, Y., and Makino, Y.: Some optical properties of smoke aerosol in Indonesia and tropical Australia, Geophys. Res. Lett., 26, 1393-1396, 1999.

Gysel, M., Weingartner, E., Nyeki, S., Paulsen, D., Baltensperger, U., Galambos, I., and Kiss, G.: Hygroscopic properties of water-soluble matter and humic-like organics in atmospheric fine aerosol, Atmos. Chem. Phys., 4, 35-50, https://doi.org/10.5194/acp-4-35-2004, 2004.

Gysel, M., Crosier, J., Topping, D. O., Whitehead, J. D., Bower, K. N., Cubison, M. J., Williams, P. I., Flynn, M. J., McFiggans, G. B., and Coe, H.: Closure study between chemical composition and hygroscopic growth of aerosol particles during TORCH2, Atmos. Chem. Phys., 7, 6131-6144, https://doi.org/10.5194/acp7-6131-2007, 2007.

Gysel, M., McFiggans, G. B., and Coe, H.: Inversion of tandem differential mobility analyser (TDMA) measurements, J. Aerosol Sci., 40, 134-151, 2009.

Hikmatullah and Sukarman: Physical and Chemical Properties of Cultivated Peat Soils in Four Trial Sites of ICCTF in Kalimantan and Sumatra, Indonesia, J. Trop Soils, 19, 131-141, https://doi.org/10.5400/jts.2014.19.3.131, 2014.

Iinuma, Y., Brüggemann, E., Gnauk, T., Müller, K., Andreae, M. O., Helas, G., Parmar, R., and Herrmann, H.: Source characterization of biomass burning particles: The combustion of selected European conifers, African hardwood, savanna grass, and German and Indonesian peat, J. Geophys. Res., 112, D08209, https://doi.org/10.1029/2006JD007120, 2007. 
Jimenez, J. L., Canagaratna, M. R., Donahue, N. M., Prevot, A. S. H., Zhang, Q., Kroll, J. H., DeCarlo, P. F., Allan, J. D., Coe, H., Ng, N. L., Aiken, A. C., Docherty, K. S., Ulbrich, I. M., Grieshop, A. P., Robinson, A. L., Duplissy, J., Smith, J. D., Wilson, K. R., Lanz, V. A., Hueglin, C., Sun, Y. L., Tian, J., Laaksonen, A., Raatikainen, T., Rautiainen, J., Vaattovaara, P., Ehn, M., Kulmala, M., Tomlinson, J. M., Collins, D. R., Cubison, M. J., Dunlea, J., Huffman, J. A., Onasch, T. B., Alfarra, M. R., Williams, P. I., Bower, K., Kondo, Y., Schneider, J., Drewnick, F., Borrmann, S., Weimer, S., Demerjian, K., Salcedo, D., Cottrell, L., Griffin, R., Takami, A., Miyoshi, T., Hatakeyama, S., Shimono, A., Sun, J. Y, Zhang, Y. M., Dzepina, K., Kimmel, J. R., Sueper, D., Jayne, J. T., Herndon, S. C., Trimborn, A. M., Williams, L. R., Wood, E. C., Middlebrook, A. M., Kolb, C. E., Baltensperger, U., and Worsnop, D. R.: Evolution of Organic Aerosols in the Atmosphere, Science, 326, 1525-1529, 2009.

Koplitz, S. N., Mickley, L. J., Marlier, M. E., Buonocore, J. J., Kim, P. S., Liu T., Sulprizio, M. P., DeFries, R. S., Jacob, D. J., Schwartz, J., Pongsiri, M., and Myers, S. S.: Public health impacts of the severe haze in Equatorial Asia in SeptemberOctober 2015: demonstration of a new framework for informing fire management strategies to reduce downwind smoke exposure, Environ. Res. Lett., 11, 094023, https://doi.org/10.1088/17489326/11/9/094023, 2016.

Kunii, O., Kanagawa, S., Yajima, I., Hisamatsu, Y., Yamamura, S., Amagai, T., Ismail, and Ir, T. S.: The 1997 Haze Disaster in Indonesia: Its Air Quality and Health Effects, Arch. Environ. Health: An International Journal, 57, 16-22, 2002.

Kuwata, M. and Lee, W.-C.: 1-Octanol-Water Partitioning as a Classifier of Water Soluble Organic Materials: Implication for Solubility Distribution, Aerosol Sci. Technol., 51, 602-613, 2017.

Kuwata, M., Kai, F. M., Yang, L., Itoh, M., Gunawan, H., and Harvey, C. F.: Temperature and Burning History Affect Emissions of Greenhouse Gasses and Aerosol Particles from Tropical Peatland Fire, J. Geophys. Res.-Atmos., 121, 1281-1292, 2017.

Levine, J. S.: The 1997 fires in Kalimantan and Sumatra, Indonesia: Gaseous and particulate emissions, Geophys. Res. Lett., 26, 815818, 1999.

Marlier, M. E., DeFries, R. S., Voulgarakis, A., Kinney, P. L., Randerson, J. T., Shindell, D. T., Chen, Y., and Faluvegi, G.: El Niño and health risks from landscape fire emissions in southeast Asia, Nat. Clim. Change, 3, 131-136, 2013.

Marlier, M. E., DeFries, R. S., Kim, P. S., Gaveau, D. L. A., Koplitz, S. N., Jacob, D. J., Mickley, L. J., Margono, B. A., and Myers., S. S.: Fire emissions and regional air quality impacts from fires in oil palm, timber, and logging concessions in Indonesia, Environ. Res. Lett., 10, 085005, https://doi.org/10.1088/17489326/10/8/085005, 2015.

Massling, A., Wiedensohler, A., Busch, B., Neusüß, C., Quinn, P., Bates, T., and Covert, D.: Hygroscopic properties of different aerosol types over the Atlantic and Indian Oceans, Atmos. Chem. Phys., 3, 1377-1397, https://doi.org/10.5194/acp-3-1377-2003, 2003.

Massling, A., Leinert, S., Wiedensohler, A., and Covert, D.: Hygroscopic growth of sub-micrometer and one-micrometer aerosol particles measured during ACE-Asia, Atmos. Chem. Phys., 7, 3249-3259, https://doi.org/10.5194/acp-7-3249-2007, 2007.

Mayol-Bracero, O. L., Guyon, P., Graham, B., Roberts, G., Andreae, M. O., Decesari, S., Facchini, M. C., Fuzzi, S., and Ar- taxo, P.: Water-soluble organic compounds in biomass burning aerosols over Amazonia 2. Apportionment of the chemical composition and importance of the polyacidic fraction, J. Geophys. Res.-Atmos., 107, 8291, https://doi.org/10.1029/2001JD000522, 2002.

Mircea, M., Facchini, M. C., Decesari, S., Cavalli, F., Emblico, L., Fuzzi, S., Vestin, A., Rissler, J., Swietlicki, E., Frank, G., Andreae, M. O., Maenhaut, W., Rudich, Y., and Artaxo, P.: Importance of the organic aerosol fraction for modeling aerosol hygroscopic growth and activation: a case study in the Amazon Basin, Atmos. Chem. Phys., 5, 3111-3126, https://doi.org/10.5194/acp5-3111-2005, 2005.

Ng, N. L., Canagaratna, M. R., Zhang, Q., Jimenez, J. L., Tian, J., Ulbrich, I. M., Kroll, J. H., Docherty, K. S., Chhabra, P. S., Bahreini, R., Murphy, S. M., Seinfeld, J. H., Hildebrandt, L., Donahue, N. M., DeCarlo, P. F., Lanz, V. A., Prévôt, A. S. H., Dinar, E., Rudich, Y., and Worsnop, D. R.: Organic aerosol components observed in Northern Hemispheric datasets from Aerosol Mass Spectrometry, Atmos. Chem. Phys., 10, 46254641, https://doi.org/10.5194/acp-10-4625-2010, 2010.

Ng, N. L., Canagaratna, M. R., Jimenez, J. L., Chhabra, P. S., Seinfeld, J. H., and Worsnop, D. R.: Changes in organic aerosol composition with aging inferred from aerosol mass spectra, Atmos. Chem. Phys., 11, 6465-6474, https://doi.org/10.5194/acp11-6465-2011, 2011.

Page, S. E., Siegert, F., Rieley, J. O., Boehm, H.-D. V., Jaya, A., and Limin, S.: The amount of carbon released from peat and forest fires in Indonesia during 1997, Nature, 420, 61-65, 2002.

Peng, C., Chan, M. N., and Chan, C. K.: The hygroscopic properties of dicarboxylic and multifunctional acids: Measurements and UNIFAC predictions, Environ. Sci. Technol., 35, 4495-4501, 2001.

Petters, M. D. and Kreidenweis, S. M.: A single parameter representation of hygroscopic growth and cloud condensation nucleus activity, Atmos. Chem. Phys., 7, 1961-1971, https://doi.org/10.5194/acp-7-1961-2007, 2007.

Petters, M. D. and Kreidenweis, S. M.: A single parameter representation of hygroscopic growth and cloud condensation nucleus activity - Part 2: Including solubility, Atmos. Chem. Phys., 8, 6273-6279, https://doi.org/10.5194/acp-8-6273-2008, 2008.

Petters, M. D., Carrico, C. M., Kreidenweis, S. M., Prenni, A. J., DeMott, P. J., Collett Jr., J. L., and Moosmuller, H.: Cloud condensation nucleation activity of biomass burning aerosol, J. Geophys. Res.-Atmos., 114, D22205, https://doi.org/10.1029/2009JD012353, 2009.

Petters, M. D., Kreidenweis, S. M., and Ziemann, P. J.: Prediction of cloud condensation nuclei activity for organic compounds using functional group contribution methods, Geosci. Model Dev., 9, 111-124, https://doi.org/10.5194/gmd-9-111-2016, 2016.

Polidori, A., Turpin, B. J., Davidson, C. I., Rodenburg, L. A., and Maimone, F.: Organic $\mathrm{PM}_{2.5}$ : Fractionation by Polarity, FTIR Spectroscopy, and OM/OC Ratio for the Pittsburgh Aerosol, Aerosol Sci. Technol., 42, 233-246, 2008.

Psichoudaki, M. and Pandis, S. N.: Atmospheric Aerosol WaterSoluble Organic Carbon Measurement: A Theoretical Analysis, Environ. Sci. Technol., 47, 9791-9798, 2013.

Reddington, C. L., Yoshioka, M., Balasubramanian, R., Ridley, D., Toh, Y. Y., Arnold, S. R., and Spracklen, D. V.: Contribution of vegetation and peat fires to particulate air pol- 
lution in Southeast Asia, Environ. Res. Lett., 9, 094006, https://doi.org/10.1088/1748-9326/9/9/094006, 2014.

Riipinen, I., Rastak, N., and Pandis, S. N.: Connecting the solubility and $\mathrm{CCN}$ activation of complex organic aerosols: a theoretical study using solubility distributions, Atmos. Chem. Phys., 15, 6305-6322, https://doi.org/10.5194/acp-15-6305-2015, 2015.

Rose, D., Gunthe, S. S., Mikhailov, E., Frank, G. P., Dusek, U., Andreae, M. O., and Pöschl, U.: Calibration and measurement uncertainties of a continuous-flow cloud condensation nuclei counter (DMT-CCNC): CCN activation of ammonium sulfate and sodium chloride aerosol particles in theory and experiment, Atmos. Chem. Phys., 8, 1153-1179, https://doi.org/10.5194/acp8-1153-2008, 2008.

Rose, D., Nowak, A., Achtert, P., Wiedensohler, A., Hu, M., Shao, M., Zhang, Y., Andreae, M. O., and Pöschl, U.: Cloud condensation nuclei in polluted air and biomass burning smoke near the mega-city Guangzhou, China - Part 1: Size-resolved measurements and implications for the modeling of aerosol particle hygroscopicity and CCN activity, Atmos. Chem. Phys., 10, 33653383, https://doi.org/10.5194/acp-10-3365-2010, 2010.

Simoneit, B. R. T., Schauer, J. J., Nolte, C. G., Oros, D. R., Elias, V. O., Fraser, M. P., Rogge, W. F., and Cass, G. R.: Levoglucosan, a tracer for cellulose in biomass burning and atmospheric particles, Atmos. Environ., 33, 173-182, 1999.

Spracklen, D.V., Reddington C. L., and Gaveau, D. L. A.: Industrial concessions, fires and air pollution in Equatorial Asia, Environ. Res. Lett., 10, 091001, https://doi.org/10.1088/17489326/10/9/091001, 2015.

Stockwell, C. E., Jayarathne, T., Cochrane, M. A., Ryan, K. C., Putra, E. I., Saharjo, B. H., Nurhayati, A. D., Albar, I., Blake, D. R., Simpson, I. J., Stone, E. A., and Yokelson, R. J.: Field measurements of trace gases and aerosols emitted by peat fires in Central Kalimantan, Indonesia, during the 2015 El Niño, Atmos. Chem. Phys., 16, 11711-11732, https://doi.org/10.5194/acp-16-117112016, 2016.

Suda, S. R., Petters, M. D., Yeh, G. K., Strollo, C., Matsunaga, A., Faulhaber, A., Ziemann, P. J., Prenni, A. J., Carrico, C. M., Sullivan, R. C., and Kreidenweis, S. M.: Influence of Functional Groups on Organic Aerosol Cloud Condensation Nucleus Activity, Environ. Sci. Technol., 48, 10182-10190, 2014.
Sullivan, A. P. and Weber, R. J.: Chemical characterization of the ambient organic aerosol soluble in water: 1. Isolation of hydrophobic and hydrophilic fractions with a XAD-8 resin, J. Geophys. Res., 111, D05314, https://doi.org/10.1029/2005JD006485, 2006.

Suzuki, Y., Kawakami, M., and Akasaka, K.: ${ }^{1} \mathrm{H}$ NMR Application for Characterizing Water-Soluble Organic Compounds in Urban Atmospheric Particles, Environ. Sci. Technol., 35, 2656-2664, 2001.

Tang, I. N. and Munkelwitz, H. R.: Water activities, densities, and refractive indices of aqueous sulfates and sodium nitrate droplets of atmospheric importance, J. Geophys. Res.-Atmos., 99, 1880118808,1994

Turpin, B. J., Hering, S. V., and Huntzicker, J. J.: Investigation of organic aerosol sampling artifacts in the Los Angeles Basin, Atmos. Environ., 28, 3061-3071, 1994.

Usup, A., Hashimoto, Y., Takahashi, H., and Hayasaka, H.: Combustion and thermal characteristics of peat fire in tropical peatland in Central Kalimantan, Indonesia, Tropics, 14, 1-19, 2004.

Valvani, S. C., Yalkowsky, S. H., and Roseman, T. J.: Solubility and partitioning IV: Aqueous solubility and octanol-water partition coefficients of liquid nonelectrolytes, J. Pharmaceutical Sci., 70, 502-507, 1981.

van der Werf, G. R., Randerson, J. T., Giglio, L., Collatz, G. J., Mu, M., Kasibhatla, P. S., Morton, D. C., DeFries, R. S., Jin, Y., and van Leeuwen, T. T.: Global fire emissions and the contribution of deforestation, savanna, forest, agricultural, and peat fires (1997-2009), Atmos. Chem. Phys., 10, 11707-11735, https://doi.org/10.5194/acp-10-11707-2010, 2010.

Wang, Y., Field, R. D., and Roswintiarti, O.: Trends in atmospheric haze induced by peat fires in Sumatra Island, Indonesia and El Niño phenomenon from 1973 to 2003, Geophys. Res. Lett., 31, L04103, https://doi.org/10.1029/2003GL018853, 2004. 